\title{
Penerapan Paket Teknologi Pemupukan Organik-Anorganik Untuk Tanaman Cabai Merah di Lahan Kering Lombok Utara
}

\author{
Zaenal Arifin*, Lolita Endang Susilowati, Mansur Ma'shum \\ Prodi Ilmu Tanah, Fakultas Pertanian, Universitas Mataram, Mataram, Indonesia
}

\author{
Article history \\ Received: 09 Desember 2019 \\ Revised: 27 Januari 2020 \\ Accepted: 26 Maret 2020 \\ *Corresponding Author: \\ Zaenal Ariin \\ Prodi Ilmu Tanah, Faperta \\ UNRAM, Universitas \\ Mataram, Mataram, Indonesia \\ Email: zn.ariin@yahoo.co.id
}

\begin{abstract}
Increased productivity of red chili plants is done to meet consumer demand which continues to increase by increasing cultivation techniques, one of which is fertilization. So far, farmers on dry land only rely on the use of high amounts of inorganic fertilizers. While the use of inorganic fertilizers continuously without being balanced with the provision of organic fertilizers can reduce the quality and fertility of the soil. This extention service aims to (1) provide understanding and enrich knowledge to farmers in the dry land of North Lombok regency to use a combination of organic and inorganic fertilizers in the cultivation of red chili, (2) practicing red chili cultivation techniques by giving a combination of organic and inorganic fertilizers. Community service was carried out within a period of six months to the "Tani Tulen" farmer group partners in Sambik Rindang hamlet, Salut village, Khayangan sub-district, North Lombok district. The approach method was used, participatory with the target empowerment process includes: (1) counseling; (2) the practice of planting red chilies with a combination of inorganic fertilizers. The results shows that (1) an increase in understanding farmers about the importance of using manure (compost) in increasing soil fertility, (2) the used of manure of 5 tons/ha combined with $350 \mathrm{~kg}$ Urea, $300 \mathrm{~kg} \mathrm{SP}-36$, and $200 \mathrm{~kg} \mathrm{KCl}$ provide good growth in red chili plants.
\end{abstract}

Keywords: extention; dry-land; empowerment; manure; participation

Abtrak: Peningkatan produktivitas tanaman cabai merah dilakukan untuk memenuhi permintaan konsumen yang terus meningkat dengan meningkatkan tehnik budidaya, salah satunya adalah pemupukan. Selama ini petani di lahan kering hanya mengandalkan penggunaan pupuk anorganik dengan dosis tinggi, dan secara terus menerus tanpa diimbangi dengan pemberian pupuk organik sehingga dapat menurunkan kualitas dan kesuburan tanah. Kegiatan pengabdian ini bertujuan (1) memberikan pemahaman dan memperkaya pengetahuan kepada petani di lahan kering kabupaten Lombok Utara untuk menggunakan kombinasi pupuk organik dan anorganik dalam cabai merah, (2) mempraktekan tehnik bercocok tanam cabai merah dengan pemberian kombinasi pupuk organik dan anorganik. Kegiatan ini dilaksanakan dalam waktu enam bulan dengan sasaran mitra kelompok tani "Tani Tulen" di dusun Sambik Rindang desa Salut kecamatan Khayangan kabupaten Lombok Utara. Metode pendekatan yang digunakan adalah partisipatif dengan proses pemberdayaan sasaran meliputi: (1) penyuluhan; (2) kegiatan praktek penanaman cabai merah dengan kombinasi pupuk organik- anorganik. Hasil pengabdian menunjukkan bahwa (1) Terjadi peningkatan pemahaman petani tentang pentingnya penggunaan pupuk kandang (kompos) dalam meningkatkan kesuburan tanah, (2) Pemberian pupuk kandang 5 ton/ha yang dikombinasikan dengan pupuk Urea-350 kg, SP-36-300 kg, dan KCl-200 kg memberikan pertumbuhan yang baik pada tanaman cabai merah. 
Kata Kunci: lahan kering; penyuluhan; partisipatif; pemberdayaan; pupuk kandang;

\section{PENDAHULUAN}

Pengembangan usaha pertanian untuk sayuran terutama cabai merah di lahan kering yang sebagian besar mendominasi lahan pertanian di NTB saat ini terus dilakukan. Kegiatan ini mendapatkan tantangan yang cukup besar dengan potensi lahan kering yang mempunyai sumber daya alam dan manusia yang terbatas. Usaha mengoptimalkan pemanfaatan lahan kering tidak terlepas dari serangkaian kegiatan untuk memperbaiki kesuburan tanah. Pada umumnya, karakteristik tanah di lahan kering dicirikan dengan tekstur tanah kasar (pasir berloam), kandungan C-organik rendah (kurang dari 1\%), kekurangan unsur N, kandungan P-tersedia berstatus rendah (Kusumo dkk, 2011), serta populasi dan keragaman mikrobia tanah pendaur hara juga rendah (Susilowati dan Kusumo, 2012). Dengan keterbatasan tingkat kesuburan tanah tersebut menyebabkan rata-rata hasil budidaya cabai merah yang dikembangkan hanya mencapai 5,5 ton/ha, sedangkan potensi produksinya dapat mencapai 20 ton/ha (Anonim, 2007).

Usaha meningkatkan produksi cabai merah oleh petani selama ini terus dilakukan dengan mengintroduksi varitas yang tahan kekeringan dan dengan pemupukan. Varietas sangat menentukan produktivitas. Varietas yang sesuai keadaan lingkungan terutama tahan kekeringan diharapkan tumbuh dengan baik dan memberikan hasil yang tinggi. Penggunaan varietas unggul harus diimbangi dengan penyediaan unsur hara dalam jumlah yang mencukupi selama fase pertumbuhan tanaman.

Selama ini petani di lahan kering mengandalkan penggunaan pupuk anorganik (kimia) dengan alasan kandungan unsur hara tinggi, mudah didapat, dan cepat memberikan hasil. Pada satu sisi, pemakaian pupuk seperti ini dalam jangka waktu yang lama bukan memberikan hasil yang positif, melainkan dapat memberikan pengaruh negatif karena pupuk kimia dapat menurunkan kesuburan fisika, kimia, dan biologi tanah. Hal ini mengakibatkan kemampuan tanah untuk memegang, mempertahankan, menyediakan unsur hara semakin menurun sehingga potensi kehilangan unsur hara terutama lewat air pengatusan semakin besar (Ma'shum, 2005). Hal ini dapat dilihat dari jumlah pemberian pupuk anorganik yang terus meningkat dari tahun ke tahun. Oleh karena itu, petani harus mengeluarkan biaya produksi yang terus meningkat, sementara mereka memiliki keterbatasan modal. Salah satu alternatif perbaikan kesuburan tanah yang dapat dilakukan untuk mengatasi permasalahan ini dan sangat perlu diintroduksi kepada petani lahan kering adalah dengan pemberian pupuk kombinasi "anorganik-organik".

Pupuk organik maupun anorganik mempunyai perbedaan, di antaranya dalam hal kecepatan penyedian unsur hara dari pupuk organik tergolong lambat dibandingkan pupuk anorganik sehingga pengaruh yang ditimbulkan pupuk organik terhadap pertumbuhan yang terjadi pada tanaman berlangsung lambat dibandingkan pupuk anorganik yang berlangsung cepat. Sebaliknya, susunan unsur hara yang dikandung dalam pupuk organik lebih lengkap dibandingkan pupuk anorganik. Disamping itu, pupuk organik sangat berperan dalam memperbaiki (1) sifat fisik tanah yaitu memperbaiki kemantapan agregat dan warna tanah, (2) sifat kimia tanah yaitu meningkatkan ketersediaan hara bagi tanaman dan KPK tanah, dan (3) sifat biologi tanah yaitu meningkatkan aktivitas biologi tanah (Ma'shum, 2005). Mengkombinasikan penggunaan pupuk organik dan anorganik diharapkan dapat mengurangi penggunaan pupuk anorganik dengan capaian produksi yang optimal dan tetap mempertahankan tingkat kesuburan tanah di lahan kering. Pemberian pupuk kandang 5-10 ton/ha dengan setengah takaran rekomendasi pupuk anorganik terbukti dapat 
memperbaiki kesuburan tanah dan perolehan hasil pertanaman di lahan kering (Ma'shum, 2005; Kusumo, 2011). Tujuan kegiatan pengabdian ini adalah 1) Memberikan pemahaman dan memperkaya pengetahuan kepada petani di lahan kering kabupaten Lombok Utara untuk menggunakan kombinasi pupuk organik dan anorganik dalam budidaya sayuran khususnya cabai merah; 2) Mempraktekan tehnik bercocok tanam cabai merah dengan pemberian kombinasi pupuk organik dan anorganik.

\section{METODE}

Pengabdian pada masyarakat dilaksanakan selama enam bulan pada kelompok tani "Tani Tulen" di dusun Sambik Rindang desa Salut kecamatan Khayangan kabupaten Lombok Utara. Metode pendekatan yang digunakan adalah partisipatif dengan melibatkan kelompok tani sasaran mulai dari proses perencanaan, pelaksanaan sampai dengan monitoring dan evaluasi kegiatan. Pendekatan partisipasif dimaksudkan untuk memberikan ruang seluas-luasnya kepada sasaran agar terlibat secara aktif dalam penggalian gagasan dan pengambilan keputusan mulai dari tahap persiapan, pelaksanaan sampai dengan monev pelaksanaan kegiatan. Langkah-langkah dalam proses pengabdian meliputi penyuluhan dan praktek. Petani sasaran tidak hanya sebagai obyek kegiatan tetapi juga sebagai pelaku pengkaji teknologi dan sekaligus pengevaluasi kesesuaian teknologi bedasarkan kriteria mereka, sedangkan tim pengabdian bertindak sebagai fasilitator. Komitmen sinergi antara tim pengabdian dan petani sebagai sasaran sangat penting untuk mencapai target dan luaran kegiatan.

Persiapan dan Pelaksanaan Pengabdian kepada Petani

Kegiatan pengabdian kepada masyarakat dengan kelompok tani sasaran diawali dengan pertemuan dan perencanaan kegiatan antara tim pengabdian dan kelompok tani Tani Tulen di Sambik Rindang sebagai mitra yang diwakili oleh 5 orang kader. Pada tahapan ini membahas rencana pelaksanaan kegiatan dan sekaligus penetapan rencana kerja secara bersama yang meliputi (1) bagaimana kegiatan dilakukan; (2) penetapan waktu pelaksanaana; (3) penetapan tempat-tempat pelaksanaan kegiatan; (4) bentuk tanggung jawab dan komitmen untuk melaksanakan kegiatan ini. Tahap kegiatan ini dimaksudkan untuk menumbuhkan rasa tanggungjawab mitra sasaran atas terlaksananya kegiatan bersama ini dalam rangka mencapai target kegiatan.

Kegiatan penyuluhan dengan metode ceramah dan diskusi yang diikuti oleh seluruh anggota kelompok tani sasaran sebagai mitra (25 orang). Kegiatan ini bertujuan untuk memperkaya khasanah pengetahuan mitra sasaran mengenai (1) Faktor-faktor yang mempengaruhi tingkat keberhasilan sistim bercocok tanam di lahan kering, (2) Tehnik bercocok tanam sayuran khususnya cabai merah dengan memanfaatkan pupuk kandang sebagai pupuk organik yang dikombinasikan dengan pupuk anorganik.

Kegiatan praktik teknik bertanam cabai merah dengan kombinasi pupuk organik dan organik bertujuan untuk meningkatkan pengetahuan dan keterampilan petani lahan kering sebagai mitra sasaran dalam melakukan tehnik bertanam cabai dengan memanfaatkan pupuk kandang. Dari kegiatan ini diharapkan petani sasaran dapat melakukan sendiri penanaman cabai merah secara tepat mulai dari tahap persiapan lahan pertanian dengan pemberian pupuk kandang dan pupuk kandang sebagai pupuk dasar, pemilihan bibit dan pembibitan, penyiraman, pemupukan susulan, perawatan terutama dalam pemantauan serangan hama dan penyakit, dan panen serta penanganan pasca panen.

\section{HASIL DAN PEMBAHASAN}

\section{Konfirmasi dan Koordinasi dengan PPL}

Kegiatan ini diawali dengan tahap konfirmasi dan koordinasi dengan PPL tempat direncanakan kegiatan. Maksud dari kegiatan ini adalah untuk menyamakan persepsi tentang penetapan lokasi dan 
kelompok tani sasaran sebagai tempat pelaksanaan kegiatan. Setelah dilakukan diskusi dan dengan mempertimbangkan semua aspek, maka lokasi pengabdian ditetapkan pada kelompok Tani "Tani Tulen" di dusun Sambik Rindang desa Salut kecamatan Khayangan kabupaten Lombok Utara. Pemilihan lokasi ini selain karena pertimbangan prasarana jalan yang memadai (meskipun kondisi jalan tidak begitu baik) sehingga memperlancar pelaksanaan kegiatan juga didukung dengan ketersediaan sumur dan mesin pompa sehingga sangat menunjang pelaksanaan kegiatan pada musim kemarau. Disamping itu juga disebabkan adanya motivasi yang tinggi dari masyarakat sekitar dalam menyambut kegiatan pengabdian ini.

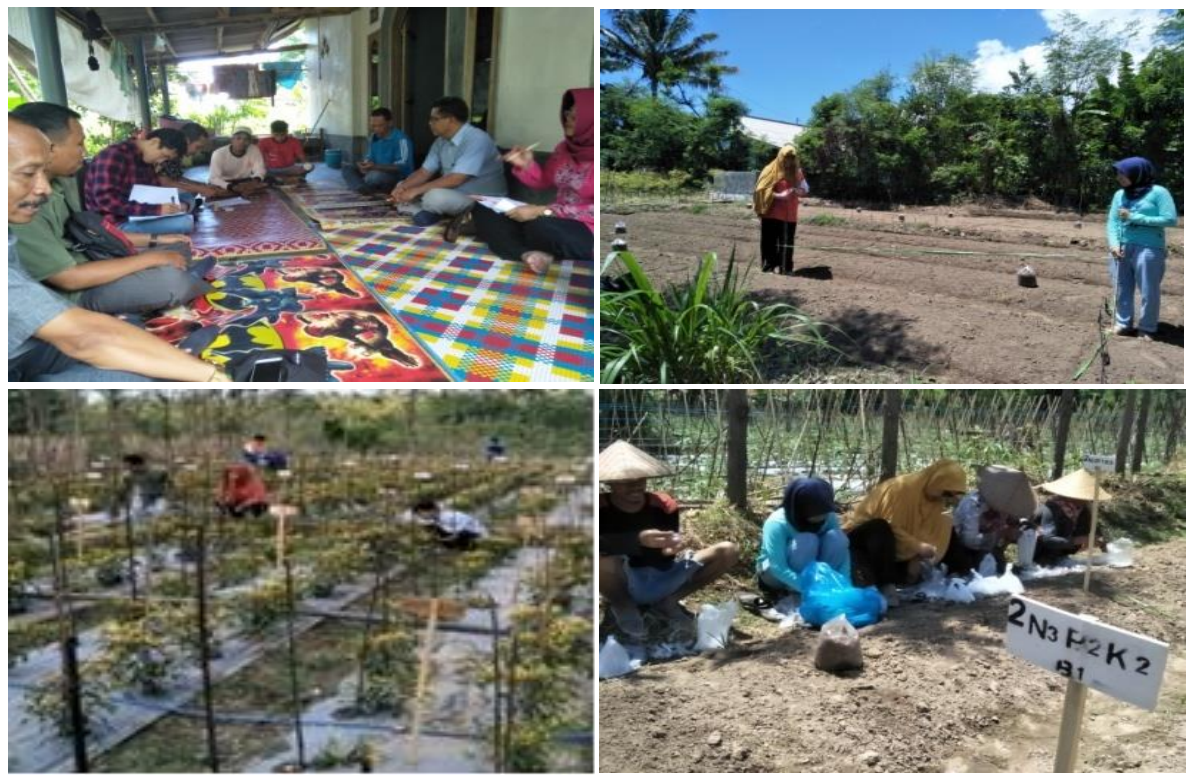

Gambar 1. Rangkaian kegiatan pengabdian pada masyarakat kelompok tani "Tani Tulen" di dusun Sambik Rindang desa Salut kecamatan Khayangan kabupaten Lombok Utara. Sosialiasi dan penyampaian materi serta diskusi bersama PPL dan petani sasaran (kiri atas), kegiatan pengolahan tanah dan pembibitan (kanan atas); kegiatan pemupukan (kanan bawah), dan pemanenan cabe merah hasil praktek pemupukan (kiri bawah).

\section{Demplot Penanaman Cabai}

Pelaksanaan kegiatan demplot tanaman cabai dilakukan di lahan petani milik pak Lalu Kadir yang merupakan ketua kelompok Tani "Tani Tulen” di dusun Sambik Rindang desa Salut kecamatan Khayangan kabupaten Lombok Utara dengan luasan $1.000 \mathrm{~m}^{2}$. Pelaksanaan demplot dilakukan ditengah-tengah lahan petani, dimana petani juga melakukan penanaman cabai diluar demplot dengan cara dan tehnik budidaya yang selama ini dilakukan. Hal ini sangat baik untuk pembelajaran petani, kelompok tani pelaksana dan kelompok tani bukan pelaksana atau bukan mitra, dimana dapat langsung melihat perbandingan mulai dari tingkat pertumbuhan sampai panen antara tanaman cabai dalam demplot dan diluar demplot. Pelaksanaan demplot dilakukan setelah panen tomat dan memasuki awal musim kemarau yaitu bulan April 2018. Pemilihan waktu tanam ini dengan harapan bahwa ketika panen nanti petani dapat menjual cabai dengan harga yang masih baik dan menguntungkan karena pada saat itu memasuki moment besar yaitu puasa bulan Ramadan dan Hari Raya Idul Fitri yang biasanya permintaan akan komoditas ini sangat tinggi. 
Pembuatan demplot dilakukan bersama-sama dengan petani pelaksana, mulai dari pembersihan lahan, pengolahan tanah, pembuatan bedengan, dan pemasangan mulsa plastik. Bersamaan dengan pembuatan demplot, pembibitan cabai juga dilakukan dengan menggunakan plastik kecil yang diisi media tanah dan pupuk kandang dengan perbandingan 1 : 1. Pembibitan dilakukan selama 20 hari atau telah tumbuh daun dua tingkat yang menandakan bibit siap dipindah ke demplot. Varitas cabai yang digunakan adalah varitas Dewata. Pemilihan varitas ini berdasarkan keinginan kelompok tani sasaran dengan pertimbangan bahwa varitas ini lebih cepat anen (umur 60 70 HST) dan tahan serangan hama penyakit.

Pembuatan bedengan dengan ukuran 1 meter x 10 meter dengan ketinggian bedengan $30 \mathrm{~cm}$. Jarak tanam yang diterapkan adalah $60 \times 70 \mathrm{~cm}$ sehingga jumlah populasi per hektar adalah 23.810 tanaman. Pupuk yang digunakan adalah penerapan kombinasi pupuk organik dan organik. Pupuk organik dengan dosis 5 ton/ha atau setara dengan $500 \mathrm{~kg}$ pupuk kandang pada luasan demplot 1000 $\mathrm{m} 2$. Sedangkan pemberian pupuk anorganik per hektar adalah Urea $=350 \mathrm{~kg}, \mathrm{SP}-36=300 \mathrm{~kg}$, dan $\mathrm{KCl}=200 \mathrm{~kg}$. Pemberian pupuk kandang dilakukan bersamaan dengan pengolahan tanah dengan cara dibenamkan dan dicampur merata pada bedengan. Sedangkan pupuk anorganik diberikan $30 \%$ sebagai pupuk dasar yang diberikan sebelum tanam, sedangkan sisanya (70\%) diberikan sebagai pupuk susulan. Pemberian pupuk susulan dilakukan pada umur tanaman cabai memasuki 21 HST dan diberikan secara periodik dengan interval 7 hari. Pupuk dasar diberikan dalam bentuk padat pupuk, sedangkan untuk pupuk susulan setiap minggu diberikan dengan cara pupuk dilarutkan dalam air kemudian diberikan sesuai takaran per tanaman. Pemanenan cabai dilakukan apabila buah sudah masak fisiologi yaitu ditandai dengan paling sedikit $50 \%$ buah berwarna merah. Panen pertama pada demplot dilakukan pada umur 66 HST dan panen berikutnya dengan interval 7 hari.

\section{Tahap Evaluasi dan Hasil Kegiatan}

Evaluasi terhadap kegiatan ini dilakukan secara bersama-sama oleh petani peserta kegiatan dan tim pengabdian. Evaluasi dilakukan pada setiap ada pertemuan baik ditingkat lapangan maupun dalam suatu forum di rumah ketua kelompok tani dengan tim pengabdian sebagai fasilitator. Ditingkat lapangan dengan mengadakan pengamatan terhadap setiap fase pertumbuhan pada tanaman cabai. Kegiatan ini dianggap sangat penting untuk menumbuhkan kepercayaan petani pada penggunaan kombinasi pupuk organik dan anorganik dalam usaha taninya. Pengamatan terakhir dilakukan pada saat pemanenan terakhir tanaman cabai yaitu setelah 5 kali panen. Pada saat panen petani dapat membandingkan langsung hasil yang diperoleh jika menggunakan pupuk anorganik dan pupuk organik. Secara umum kegiatan evaluasi ini dimaksudkan untuk menilai secara kualitatif mengenai respon petani terhadap kegiatan pengabdian ini. Untuk menilai tinggi rendahnya respon petani dapat ditunjukkan dari persepsi, motivasi, pengetahuan,sikap, partisipasi mereka mulai dari awal sampai dengan akhir kegiatan yang mana kesemuanya dapat dilihat dari antusias mereka dalam pertemuan bersama.

Kegiatan ini dianggap berhasil karena mendapatkan respon positif dari petani sasaran, dengan indikator sebagai berikut:

a. Persepsi petani.

Pada forum diskusi yang diadakan pada akhir kegiatan berupa hari lapang tani, tim pengabdian sebagai fasilitator memberikan kesempatan pada semua anggota untuk menyampaikan pendapat tentang bercocok tanam cabai dengan kombinasi pupuk organik dan anorganik. Masing-masing mempunyai pendapat atau persepsi yang berbeda. Tetapi pada umumnya para petani sudah 
mengetahui manfaat penggunaan pupuk organik terutama sebagai peningkat kesuburan tanah. Selama penanaman para petani juga mengamati jumlah kebutuhan air. Mereka mengakui bahwa dengan penggunaan pupuk kandang jumlah air yang dibutuhkan relatif lebih sedikit dibandingkan dengan hanya mengandalkan pupuk anorganik. Dalam hal ini tim pengabdian menjelaskan bahwa tanah yang mempunyai kadar bahan organik yang tinggi mempuyai kemampuan yang baik dalam mengikat air. Sehingga kehilangan air lewat penguapan dan pencucian menjadi lebih kecil. Hal ini mempunyai peranan yang sangat besar terutama dalam pengembangan pertanian pada tanah-tanah yang didominasi fraksi pasir seperti di lokasi demplot. Sehingga penggunaan pupuk kandang akan dapat mengefisiensikan pengairan dan menjaga kualitas lahan.

b. Motivasi

Dari kegiatan ini diharapkan terbangun motivasi petani untuk menggunakan pupuk organik seperti pupuk kandang, pupuk hijau, dan kompos dalam usaha taninya. Pada umumnya para petani sudah mengetahui kegunaan pupuk organik untuk perbaikan kesuburan lahan. Akan tetapi selama ini mereka menganggap pupuk organik hanya berupa pupuk kandang saja. Sedangkan untuk mendapatkan pupuk kandang dalam jumlah yang relatif banyak sangat sulit dan membutuhkan biaya pengangkutan yang relatif mahal. Untuk itu, tim pengabdian menyarankan agar petani yang tergabung dalam kelompok tani untuk mengadakan pembuatan kompos dengan memanfaatkan limbah-limbah rumah tangga, pertanian, dan kotoran ternak yang ada di lokasi.

Setelah mengetahui manfaat dan peran kompos sebagai perbaikan kualitas tanah, maka tumbuh semangat dan motivasi petani untuk menggunakan pupuk organik ini sebagai pengganti sebagian penggunaan pupuk anorganik. Sehingga tim pengabdian beranggapan bahwa dari kegiatan ini dapat meningkatkan semangat dan motivasi petani untuk menggunakan pupuk organik sebagai imbangan penggunaan pupuk anorganik dalam memperbaiki kesuburan tanah dan meningkatkan produktivitas lahan pertanian pada lahan kering.

c. Sikap

Setelah kegiatan lapangan selesai dan selama forum diskusi berlangsung, tim pengabdian dapat mengamati adanya perubahan sikap yang ditunjukkan oleh petani peserta, yaitu terjadi perubahan pola pikir oleh petani yang ditunjukkan oleh perubahan sikap dalam mencermati dan menerima setiap informasi baru yang disampaikan, baik oleh anggota petani yang lain maupun informasi yang diberikan oleh tim pengabdian. Hal ini merupakan perubahan sikap yang positif dalam memajukan pertanian khususnya tanaman cabai di lahan kering.

Sikap petani biasanya cederung untuk melakukan sesuatu, apakah petani mendukung, menerima atau menolaknya. Sikap petani tergolong tinggi dalam menerima tambahan pengetahuan ini. Petani peserta kegiatan memberikan tanggapan positif terhadap penggunaan pupuk kandang yang dikombinasikan pupuk anorganik. Petani sangat setuju dengan adanya program dan menyatakan program ini merupakan program yang dapat memberikan keuntungan kepada petani di lahan kering

\section{KESIMPULAN DAN SARAN}

\section{Kesimpulan}

Kegiatan ini dapat meningkatkan pemahaman petani tentang pentingnya penggunaan pupuk kandang (kompos) dalam meningkatkan kesuburan tanah dan meningkatkan motivasi petani dalam pengembangan tanaman cabai pada lahan kering, dikarenakan ada perubahan sikap para petani dalam menerima setiap informasi, terutama dalam menjaga dan meningkatkan kualitas lahan untuk 
mendukung pertanian yang berkelanjutan. Pemberian pupuk kandang 5 ton/ha yang dikombinasikan dengan $350 \mathrm{~kg}$ pupuk Urea, $300 \mathrm{~kg} \mathrm{SP-36,} \mathrm{dan} 200 \mathrm{~kg} \mathrm{KCl}$ dapat memberikan pertumbuhan yang baik pada tanaman cabai merah.

\section{Saran}

Dari kegiatani pengabdian ini disarankan untuk peningkatan produksi cabai merah di lahan kering dengan menggunakan paket pemupukan pupuk kandang 5 ton/ha yang dikombinasikan dengan pupuk Urea sebanyak $350 \mathrm{~kg}$, SP-36 sebanyak $300 \mathrm{~kg}$, dan KCl sebanyak $200 \mathrm{~kg}$.

\section{Ucapan Terima Kasih}

Penulis mengucapkan terima kasih kepada LPPM Universitas Mataram yang telah memberi dukungan financial terhadap pengabdian ini melalui kegiatan PNBP.

\section{DAFTAR PUSTAKA}

Anonim. 2007. 2013. Cabai Merah. (http://id.wikipedia.org/wiki/Cabai) [25 Pebruari 2017].

Kusumo, B.H., N. Karde, M. Ma'shum, L.E. Susilowati. 2011. Teknologi Pengembangan Sorgum Untuk Pakan Ternak di Lahan Kering Guna Mendukung Program Bumi Sejuta Sapi di Nusa Tenggara Barat. Laporan Penelitian Terapan Ristek 2011. Lembaga Penelitian Universitas Mataram.

Ma'shum, M. 2005. Kesuburan Tanah dan Pemupukan. Mataram. Mataram University Press.

Susilowati, L.E. dan B. H. Kusumo. 2012. Pemanfaatan Pupuk Organik dan Hayati Ganda MVA-BPF dalam meningkatkan Serapan Hara N, P, K dan Hasil Kacang Tanah di Lahan Kering. Prosiding Konferensi dan Seminar Nasional Badan Kerjasam Pusat Studi Lingkungan Hidup Indonesia (BKPSL) ke 21. p: 304-312. 13-15 September 2012. Mataram. 